\title{
MONITORING POPULASI NYAMUK Aedes aegypti L. VEKTOR PENYAKIT DEMAM BERDARAH DENGUE DI KELURAHAN GEDONGKIWO KECAMATAN MANTRIJERON KOTA YOGYAKARTA
}

\author{
Tri Wahyuni Sukesi \\ Fakultas Kesehatan Masyarakat Universitas Ahmad Dahlan Yogyakarta
}

\begin{abstract}
Background: Gedongkiwo Village is one of the villages that was ranked first for the highest number of dengue disease in the year 2010. Many years in the urban village health centers supported Gedongkiwo local government has sought to control the vector mosquito Ae.aegypti $\mathrm{L}$, but such efforts until now have not shown significant results. Outreach efforts and the promotion of public health for more attention to hygiene and environmental health are also able to reduce the incidence of DHF has not been clearly defined. On the other hand, another problem arises, namely the occurrence of resistance in mosquitoes Ae.aegypti L. of the pesticide compound that is used for eradication. The purpose of this study was to Knowing the population of mosquito species Ae. Aegypti L. If visits by the House Index (HI), Container Index (Cl) and Bretaeau Index (BI) in the Village District Gedongkiwo Mantrijeron Yogyakarta Special Province of Yogyakarta.

Methods: This was qualitative descriptive research. Samples in this study were 100 houses in each RW 02, 06 and 09 in the Village Gedongkiwo. Data obtained by the survey to each household to determine $\mathrm{HI}, \mathrm{Cl}$, and $\mathrm{BI}$ by filling out a check list sheet. Data analysis of the results of research carried out in accordance with two criteria: If $\mathrm{HI}>10 \%$ category of "high risk", $\mathrm{HI}<10 \%$ criterion "low risk"; if $\mathrm{Cl}>10 \%$ category of "high risk" and $\mathrm{Cl}<10 \%$ category of "low risk "; if $\mathrm{BI}>50 \%$ category of" high risk "and $\mathrm{BI}<50 \%$ category of" low risk ". Results: This study showed that the average value House Index $(\mathrm{HI})$ in the Village Gedongkiwo of 38.67 percent and the average value of Container Index $(\mathrm{Cl})$ of 13.41 percent. As for the average value of Breateu Index $(\mathrm{BI})$ is equal to 19.67 percent.

Conclusion: Based on the House Index $(\mathrm{HI})$ and the Container Index $(\mathrm{Cl})$ population of mosquitoes Ae. aegypti L. already exceeded the safe limit the spread of dengue disease. Value Breteau Index (BI) shows still below safe levels, but in alert condition with a variety of can increase dengue transmission.
\end{abstract}

Keyword: Monitoring, Population, Ae. aegypti L, Dengue Hemorhagic Fever, Gedongkiwo Village

\section{PENDAHULUAN}

Indonesia merupakan negara yang memiliki iklim tropis dan mempunyai kelimpahan sumber daya alam. Berbagai jenis flora dan fauna mampu tumbuh dengan cocok karena Indonesia mempunyai daya dukung lingkungan yang sangat baik untuk pertumbuhan keanekaragamannya. Salah satu jenis fauna yang berkembang dengan baik adalah serangga (insecta). Anggota filum Arthropoda kelas Insecta yang berkembang dengan baik salah satunya adalah nyamuk Ae.aegypti L. Perkembangan nyamuk Ae.aegypti L. menimbulkan masalah karena menjadi vektor terjadinya penyakit demam berdarah dengue (DBD). Nyamuk Ae.aegypti $L$. ini hidup dan berkembang dengan baik di daerah tropis yaitu pada garis isotermis $20^{\circ}$ yang terletak diantara $45^{\circ} \mathrm{LU}$ dan $35^{\circ} \mathrm{LS}$ dengan ketinggian kurang dari 1000 meter di atas permukaan laut. ${ }^{1}$ Populasi nyamuk ini meningkat 
pada musim hujan dan bertepatan dengan ini jumlah kasus DBD akan meningkat.

Penyebaran nyamuk Ae. aegypti $L$. sangat dipengaruhi oleh lingkungan fisik, biologik dan kebiasaan dari masyarakat yang mendukung untuk perkembangannya. Perilaku masyarakat juga berpengaruh besar karena perilaku masyarakat dapat memberikan daya dukung lingkungan bagi perkembangan nyamuk. Kebiasaan hidup menjaga kebersihan dan kesehatan lingkungan seperti 3M (Menguras, Mengubur dan Menutup tempat penampungan air) sebagai upaya mencegah terjadinya wabah DBD. Kebiasaan menggantung baju di rumah dan aktivitas masyarakat yang memberikan akibat naiknya daya dukung lingkungan terhadap perkembangan nyamuk Ae. aegypti L. Tinggi rendahnya populasi nyamuk Ae.aegypti $L$. berpengaruh pada kejadian kasus DBD. ${ }^{1}$

Adanya kenaikan jumlah penderita DBD dari tahun ke tahun dan ditemukannya beberapa tempat yang endemis DBD menyebabkan pemerintah melakukan beberapa upaya untuk mencegah dan menanggulangi terjadinya DBD. Sejak tahun 1969 pemerintah sudah melakukan upaya fogging atau pengasapan dengan menggunakan insektisida terutama jika terjadi wabah atau outbreak.

Pengendalian vektor sebagai upaya untuk mengurangi terjadinya penyakit DBD di Kelurahan Gedongkiwo Kecamatan Mantrijeron Kota Yogyakarta sampai sekarang belum menunjukkan hasil yang signifikan. Upaya penyuluhan dan promosi kesehatan masyarakat untuk lebih memperhatikan kebersihan dan kesehatan lingkungan juga belum mampu mengurangi kejadian DBD secara jelas. Pada lain pihak muncul masalah lain yaitu terjadinya resistensi pada nyamuk Ae.aegypti $L$. terhadap senyawa pestisida yang digunakan untuk pemberantasan. Senyawa pestisida khususnya sipermetrin dan temefos. Hal ini akan mempersulit upaya pengendalian penyakit DBD karena vektor yang membawa penyakit ini lebih sulit dibasmi karena sifat resistensinya. Dosis pemakaian harus dinaikkan dan hal ini dapat menyebabkan pencemaran lingkungan.

Sanitasi lingkungan dan pemukiman juga memberikan dukungan terhadap terjadinya kasus DBD. Vektor DBD nyamuk Ae. aegypti L. membutuhkan tempat hidup yang sesuai dengan kebutuhannya untuk tumbuh dan berkembang biak. Kondisi lingkungan dan pemukiman masyarakat yang tidak bersih dan sehat dapat memberikan daya dukung lingkungan yang tinggi terhadap perkembangan nyamuk Ae. aegypti $L$. Selain itu, mobilitas dan aktivitas masyarakat dapat mempengaruhi juga tingkat kejadian DBD di suatu daerah. Widyastuti ${ }^{2}$ menyatakan bahwa faktorfaktor yang menyebabkan terjadinya kasus DBD adalah :

1. Bertambahnya jumlah penduduk

2. Urbanisasi yang tidak terencana dan terkendali

3. Manajemen sampah dan penyediaan air bersih yang tidak adekuat

4. Peningkatan dan penyebaran vektor nyamuk

5. Kurang efektifnya pengendalian nyamuk

6. Memburuknya infrastruktur di bidang kesehatan masyarakat

Upaya penanggulangan DBD dilakukan dengan thermal fogging dan larvasidasi menggunakan larvasida dengan bahan aktif temefos $1 \%$. Senyawa organofosfat temefos sudah sepuluh tahun digunakan sebagai pengendali jentik nyamuk vektor DBD Ae. aegypti L. di Kelurahan Gedongkiwo, demikian juga dengan jenis insektisida yang lain, digunakan untuk pengendalian nyamuk dewasa vektor DBD Ae. aegypti L.. Meskipun demikian hasil yang diperoleh belum dapat memuaskan. Beberapa hal yang diperkirakan menjadi penyebab peningkatan kasus DBD adalah:

1. Kondisi lingkungan fisik pemukiman penduduk memberikan peluang sebagai habitat perkembangan nyamuk Ae. aegypti L., sehingga populasi nyamuk terus meningkat.

2. Terjadinya resistensi nyamuk Ae. aegypti L. terhadap insektisida yang 
digunakan.

Kasus DBD di Kota Yogyakarta sampai saat ini masih tinggi terutama di beberapa tempat. Berdasarkan data dari Dinas Kesehatan Kota Yogyakarta tahun 2010, 3 Kelurahan yang kasus DBDnya masih tinggi adalah Kelurahan Gedongkiwo, Baciro dan Suryodiningratan. Dilaporkan total jumlah penderita DBD selama tahun 2010 di Kelurahan Gedongkiwo sebanyak 76 orang, Kelurahan Baciro 68 orang dan Kelurahan Suryodiningratan 63 orang. Tujuan penelitian ini adalah untuk mengetahui populasi spesies nyamuk Aedes aegypti L. berdasarkan nilai $\mathrm{HI}, \mathrm{Cl}$, dan $\mathrm{Bl}$ di Kelurahan Gedongkiwo, Kecamatan Mantrijeron, kota Yogyakarta.

\section{METODE PENELITIAN}

Penelitian ini merupakan penelitian kualitatif deskriptif yang bertujuan untuk mengetahui populasi nyamuk. Data diperoleh dengan cara survey langsung ke rumah-rumah. Instrumen penelitian yang digunakan adalah lembar check list. Penelitian dilakukan di Kelurahan Gedongkiwo Kecamatan Mantrijeron Kota Yogyakarta yang menurut data dari Dinas Kesehatan Kota Yogyakarta tahun 2011 pada kejadian DBD paling tinggi. Kelurahan Gedongkiwo terdiri dari 18 RW dan 86 $\mathrm{RT}$, dari $18 \mathrm{RW}$ ini diambil $3 \mathrm{RW}$ yang memiliki kasus DBD paling banyak yaitu RW 02, 06 dan 09. Sampel penelitian ini adalah 100 rumah tiap RW 02, 06 dan 09 untuk mengetahui $\mathrm{HI}, \mathrm{Cl}, \mathrm{BI}$. Pada survey larva dapat dilakukan apabila populasi atau sampelnya yaitu rumah penduduk yang diperiksa berada dalam lingkup kecil atau populasinya tidak luas maka semuanya dapat diperiksa sebagai sampel, tetapi apabila populasinya sebagai sampel berada pada lingkup yang luas seperti di kotakota atau desa yang cukup luas atau besar maka yang diperiksa minimum 50 rumah. ${ }^{3}$ Data diperoleh dengan cara survey ke tiap rumah untuk mengetahui $\mathrm{HI}, \mathrm{Cl}$, dan $\mathrm{BI}$ dengan cara mengisi lembar check list. Pengolahan data dilakukan sesuai dengan 2 kriteria yaitu ${ }^{3}$ :

a. Apabila $\mathrm{HI}>10 \%$ kategori "resiko tinggi", $\mathrm{HI}<10 \%$ kriterianya "resiko rendah"

b. Apabila $\mathrm{Cl}>10 \%$ kategori "resiko tinggi" dan $\mathrm{Cl}<10 \%$ kategori "resiko rendah"

c. Apabila $\mathrm{BI}>50 \%$ kategori "resiko tinggi" dan $\mathrm{BI}<50 \%$ kategori "resiko rendah"

\section{HASIL PENELITIAN DAN PEMBAHASAN}

\section{A. House Index (HI)}

Tabel 1. Hasil Survey Pada Rumah Penduduk di Wilayah RW 02, 06 dan 09 Kelurahan Gedongkiwo Kecamatan Mantrijeron Kota Yogyakarta Tahun 2011

\begin{tabular}{ccccc}
\hline \multirow{2}{*}{$\begin{array}{c}\text { Lokasi } \\
(\mathrm{RW})\end{array}$} & \multicolumn{3}{c}{ Rumah Yang Diperiksa } & \multirow{2}{*}{ Kategori pembacaan } \\
\cline { 2 - 4 } & Jumlah & Positif Larva & Persentase (\%) & \\
\hline 02 & 100 & 48 & 48 & Resiko tinggi \\
\hline 06 & 100 & 36 & 36 & Resiko tinggi \\
\hline 09 & 100 & 32 & 32 & Resiko tinggi \\
\hline
\end{tabular}


B. Container Index (CI)

Tabel 2. Hasil Survey Larva Pada Setiap Container di Wilayah RW 02, 06 dan 09 di Kelurahan Gedongkiwo Kecamatan Mantrijeron Kota Yogyakarta Tahun 2011

\begin{tabular}{ccccc}
\hline \multirow{2}{*}{$\begin{array}{c}\text { Lokasi } \\
(\mathrm{RW})\end{array}$} & \multicolumn{3}{c}{ Kontainer Yang Diperiksa } & Kategori \\
\cline { 2 - 4 } & Jumlah & Positif Larva & Persentase $(\%)$ & Pembacaan \\
\hline 02 & 143 & 23 & 16.08 & Beresiko tinggi \\
\hline 06 & 150 & 32 & 21.33 & Beresiko tinggi \\
\hline 09 & 142 & 4 & 2.82 & Beresiko rendah \\
\hline
\end{tabular}

\section{Breteau Index (BI)}

Tabel 3. Hasil Survey Larva Pada Setiap Kontainer Pada Rumah yang Diperiksa di Wilayah RW 02, 06 Dan 09 Di Kelurahan Gedongkiwo Kecamatan Mantrijeron Kota Yogyakarta Tahun 2011

\begin{tabular}{ccccc}
\hline $\begin{array}{c}\text { Lokasi } \\
\text { (RW) }\end{array}$ & \multicolumn{3}{c}{ Breteau Index } & $\begin{array}{c}\text { Kategori } \\
\text { Pembacaan }\end{array}$ \\
\cline { 2 - 4 } & Jumlah Rumah & Positif Larva & Persentase (\%) & Beresiko rendah \\
\hline 02 & 100 & 23 & 23 & Beresiko rendah \\
\hline 06 & 100 & 32 & 32 & Beresiko rendah \\
\hline 09 & 100 & 4 & 4 & \\
\hline
\end{tabular}

Tabel 4. Rata - Rata Nilai HI, Cl dan BI di Kelurahan Gedongkiwo Kecamatan Mantrijeron Kota Yogyakarta

\begin{tabular}{ccc}
\hline No. & Parameter & Nilai Rata - Rata $(\%)$ \\
\hline 1 & House Index $(\mathrm{HI})$ & 38.67 \\
\hline 2 & Container Index $(\mathrm{Cl})$ & 13.41 \\
\hline 3 & Breteau Index $(\mathrm{Bl})$ & 19.67 \\
\hline
\end{tabular}

Berdasarkan hasil penelitian yang dilakukan di Kelurahan Gedongkiwo Kecamatan Mantrijeron Kota Yogyakarta Propinsi Daerah Istimewa Yogyakarta pada Agustus 2011 terhadap 100 rumah diperoleh kepadatan populasi Ae. aegypti L. pada RW 02 berjumlah 48 rumah yang positif larva dengan presentase 48 persen, pada RW 06 berjumlah 36 rumah yang positif larva dengan presentase 36 persen, dan pada RW 09 berjumlah 32 rumah yang positif larva dengan presentase 32 persen. Berdasarkan hasil penelitian tersebut terlihat bahwa jumlah rumah yang positif larva pada RW 02 mempunyai jumlah rumah yang positif larva paling banyak, sedangkan yang paling kecil prosentasenya adalah RW 09. Nilai HI yang lebih dari 10 persen berarti menunjukkan daerah tersebut memiliki resiko yang tinggi terjadinya penularan DBD. ${ }^{3}$ Hal ini menunjukkan bahwa di rumah-rumah penduduk banyak yang ditemukan adanya nyamuk Ae. Aegypti $L$ yang dikhawatirkan akan menularkan penyakit DBD dari satu orang ke orang lainnya. Nyamuk $A e$. Aegypti $L$ memiliki kebiasaan menggigit berulang-ulang (multibiters) bisa pada orang yang sama ataupun pada orang yang berbeda, sehingga transfer panyakit ini dapat terjadi dengan cepat. Penularan penyakit DBD juga tidak hanya selalu terjadi di ruang lingkup rumah seseorang tapi bisa saja berasal dari tempat yang lain. Misalnya di rumah tidak terdapat nyamuk Ae. Aegypti L. tetapi ketika berkunjung ke tetangga yang kebetulan rumahnya terdapat nyamuk Ae. Aegypti L. dan terjadi gigitan nyamuk yang mengandung virus dengue maka penularan penyakit DBD dapat terjadi di sana. 
Perhitungan nilai Container Index (Cl) di RW 02, 06 dan 09 menunjukkan hasil 16.08 persen, 21.33 persen dan 2.82 persen. Nilai $\mathrm{Cl}$ diperoleh dari jumlah kontainer yang ditemukan adanya larva dibagi dengan jumlah kontainer total yang diperiksa. Pada penelitian ini ada banyak kontainer yang dicek beberapa diantaranya adalah bak mandi, drum/tangki, tempayan/ gentong, ember dan lain lainnya. Nilai Container Index $(\mathrm{Cl})$ dapat digunakan sebagai alat pembanding yang penting dalam mengevaluasi program pengendalian vektor, akan tetapi tidak begitu berguna dari sisi epidemiologis. Nilai $\mathrm{Cl}$ menggambarkan banyaknya kontainer yang positif dibandingkan dengan jumlah seluruh kontainer yang terdapat di suatu wilayah. ${ }^{4}$

Hasil penelitian ini menunjukkan nilai Breteau Index (BI) dari RW 02, 06 dan 09 berturut turut adalah 23 persen, 32 persen dan 4 persen. Nilai Breteau Index (BI) menunjukkan tingkat kepadatan dan penyebaran larva. ${ }^{5}$ Secara umum, $\mathrm{BI}$ merupakan indikator yang paling baik dibandingkan dengan $\mathrm{Cl}$ dan $\mathrm{HI}$ karena mengkombinasikan antara tempat tinggal dan kontainer. Oleh karena itu, BI mempunyai nilai signifikansi epidemiologis yang lebih besar. ${ }^{4}$ Apabila nilai BI lebih dari 50 persen berarti memiliki resiko tinggi terjadi penularan DBD.

Berdasarkan hasil penelitian ini meskipun tidak menunjukkan persentase yang mendekati 100 persen tetapi harus tetap menjadi perhatian karena meskipun tidak banyak tidak menutup kemungkinan nyamuk-nyamuk tersebut mampu menularkan penyakit DBD. Secara keseluruhan daerah Gedongkiwo memiliki karakteristik daerah yang padat penduduk. Hal ini akan memberikan peluang yang makin besar untuk terjadinya penularan DBD. Sumber air yang tidak semua rumah memiliki sumur atau PAM sehingga kebiasaan menampung air tanpa diseretai dengan kesadaran untuk melakukan $3 \mathrm{M}$ akan memberikan tempat perindukan bagi nyamuk Ae. aegypti L. Terbukti meskipun musim kemarau pada waktu penelitian masih bisa ditemukan adanya jentik nyamuk $A e$. aegypti $L$. yang berarti ada tempat yang mendukung keberadaan nyamuk untuk tumbuh dan berkembang.

\section{SIMPULAN DAN SARAN}

\section{A. Simpulan}

Berdasarkan nilai House Index $(\mathrm{HI})$ dan Container Index $(\mathrm{Cl})$ populasi nyamuk $A$ e. aegypti $L$. sudah melebihi batas aman penyebaran penyakit DBD. Nilai Breteau Index (BI) menunjukkan masih di bawah ambang batas aman tetapi dalam kondisi waspada dengan berbagai macam kemungkinnan yang bisa meningkatkan penularan DBD.

\section{B. Saran}

Berdasarkan penelitian yang telah dilakukan di Kelurahan Gedongkiwo Kecamatan Mantrijeron Kota Yogyakarta dapat diberikan beberapa saran yaitu :

1) Untuk Pemerintah

Diharapkan Pemerintah dapat memberikan anggaran khusus bagi kader jumantik agar dapat menjalankan tugasnya dengan optimal, mengingat tingginya presentase kepadatan vektor Dengue. 
2) Untuk Masyarakat

Diharapkan agar masyarakat dapat meningkatkan Perilaku Hidup Bersih dan Sehat (PHBS) yang dimulai dari diri sendiri dan lingkungan seperti Pemberantasan Sarang Nyamuk (PSN).

3) Untuk Kader Jumantik

Diharapkan agar dapat digalakkan kembali program kunjungan jumantik secara rutin dan memberikan informasi berupa penyuluhan bagi masyarakat tentang Pemberantasan Sarang Nyamuk (PSN) seperti melakukan 3M (menguras, menutup, mengubur).

\section{DAFTAR PUSTAKA}

1. Sugito, Aspek Entomologi Demam Berdarah Dengue, Dirjen P2M dan PLP, Departemen Kesehatan RI, Jakarta. 1989

2. Widyastuti, Pencegahan dan Pengendalian Dengue dan Demam Berdarah Dengue. EGC, Jakarta. 2004

3. Soedarmo, Demam Berdarah (Dengue) Pada Anak, Universitas Indonesia (UIPRESS), Jakarta. 2005

4. Pant, C.P., Self, L.S., Vector Ecology and Bionomic, Monograph on Dengue/ Dengue Haemorhagic Fever, WHO, New Delhi. 1993

5. Sungkar, S., Bionomik Aedes aegypti Vektor DBD, Majalah Kedokteran Indonesia Volume 55 (No.4):384-389, Jakarta. 2005 